УДК 339.9

JEL classification: E24, J01, J24

Коломієць О. О., канд. економ. наук, завідувач відділу соціальної стратегії иентру економічних та сочіальних досліджень НІСД

ORCID ID: 0000-0002-6876-0597

Наиіональний інститут стратегічних досліджень

\title{
ПОШИРЕННЯ ДИСТАНЦЙНОЇ ЗАЙНЯТОСТІ ЯК ФАКТОР ПІДВИЩЕННЯ ЕКОНОМІЧНОЇ СТІЙКОСТІ
}

\section{EXPANSION OF DISTANCE EMPLOYMENT AS A FACTOR OF ENHANCING THE ECONOMIC SUSTAINABILITY}

Поширення COVID-19 спричинило виникнення низки ризиків для економічної безпеки України, дія яких посилюватиметься в міру продовження карантину. Урядом було запроваджено комплекс заходів щуодо запобігання поширенню на території України захворювань на COVID-19. Водночас динамічний перебіг епідемічної ситуацї̈, негативні наслідки дії заходів, запроваджених у відповідь, та розгортання світової економічної кризи потребують зміни моделі реагування на виклики економічній безпеці. Упровадження правових та регуляторних змін, державної фінансової підтримки та організаційно-економічних механізмів є необхідними умовами забезпечення економічної $i$ сочіальної безпеки в період подолання наслідків кризи. Уведення загальнонаціонального карантину, щзо стало відповіддю на поширення коронавірусної хвороби COVID-19 в Україні та світі, прискорило тенденцію до (часткового) переходу багатьох компаній, організацій та установ до роботи у режимі дистаниійної зайнятості. На ринку прачі, так само як і в інших сферах життя, пандемія COVID-19 закріпила більшість тенденцій, щзо вже мали об'єктивні підстави і передумови для існування, оскільки їх підвалини були попередньо закладені глобальними історичними процесами. Спроможність швидко переорієнтувати бізнес на роботу в нестандартних умовах вже давно є важливим економічним активом. У статті аналізуються переваги використання дистаниійної зайнятості для роботодавців, показано, як поширення дистанційної зайнятості може сприяти підвищенню економічної стійкості держави в умовах епідемічних загроз та за інших непередбачуваних обставин. Визначено, щзо проактивна політика держави щзодо стимулювання дистанційної зайнятості потребує: удосконалення нормативно-правого поля відповідно до потреб трудових відносин нової якості; впровадження найкраших практик використання нестандартних форм зайнятості $i$ прогресивних форм організащіі пращуі у державному секторі; формування здорового конкурентного середовища через встановлення рекомендованих регламентів переходу підприємств $і$ організацій на дистаниійний режим роботи у випадку непередбачуваної cumyauiï.

Ключові слова: дистанційна зайнятість, економічна стійкість, епідемічні загрози, прогресивні форми організації праці, форми зайнятості. 
The proliferation of COVID-19 has created a number of risks to Ukraine's economic security, which will increase as quarantine continues. The government has introduced a set of measures to prevent the spread of COVID-19 in Ukraine. At the same time, the dynamic course of the epidemic situation, the negative consequences of the measures taken in response, and the unfolding of the global economic crisis require a change in the model of responding to challenges to economic security. Introduction of legal and regulatory changes, state financial support and organizational and economic mechanisms are necessary conditions for ensuring economic and social security during the period of overcoming the consequences of the crisis. The introduction of national quarantine, which was a response to the spread of COVID-19 coronavirus in Ukraine and around the world, has accelerated the trend towards (partial) transition of many companies, organizations and institutions to work in remote employment. In the labor market, as in other spheres of life, the COVID-19 pandemic has consolidated most of the trends that already had objective grounds and preconditions for existence, as their foundations were previously laid by global historical processes. The ability to quickly reorient business to work in non-standard conditions has long been an important economic asset. The article analyzes the benefits of using remote employment for employers, shows how the spread of remote employment can increase the economic stability of the state in the face of epidemic threats and other unforeseen circumstances. It is determined that the proactive policy of the state to stimulate remote employment requires: improvement of the legal framework in accordance with the needs of labor relations of a new quality; introduction of best practices in the use of non-standard forms of employment and progressive forms of labor organization in the public sector; formation of a healthy competitive environment through the establishment of recommended regulations for the transition of enterprises and organizations to remote operation in the event of an unforeseen situation.

Keywords: remote work, economic resilience, epidemic threats, progressive forms of labor organization, forms of employment.

Вступ. Ухваленням Закону «Про внесення змін до деяких законодавчих актів України, спрямованих на забезпечення додаткових соціальних та економічних гарантій у зв'язку з поширенням коронавірусної хвороби (COVID19)» [1] зроблено важливі практичні кроки для врегулювання нестандартних форм зайнятості, зокрема - дистанційної зайнятості. Передбачені Законом зміни закріпили у трудовому законодавстві поняття дистанційної зайнятості, визначили іï як тотожну до роботи на робочому місці, що надається роботодавцем (вилученням 3 поняття «трудового договору» необхідності виконувати роботу за внутрішнім розпорядком та введенням норми про те, що «виконання дистанційної (надомної) роботи не тягне за собою будь-яких обмежень обсягу трудових прав працівників»).

Ухвалені зміни до трудового законодавства суттєво впливають на характер трудових відносин, оскільки не тільки підвищують соціальний захист працівників, які працюють на умовах дистанційної зайнятості, але й дозволяють роботодавцю встановлювати режим дистанційної роботи (гнучкий режим робочого часу) локальним нормативним актом (без укладання додаткової угоди 3 
працівником) на час загрози поширення епідемії, пандемії та/або на час загрози військового, техногенного, природного чи іншого характеру. Вплив пандемії COVID-19 на різні галузі економіки описано в працях Я. Жаліла, М. Паламарчука [5], А. Веселовського, О. Александрова, В. Орлик [6], О. Малиновської [7], Я. Базилюк, Т. Гейко [8], Ю. Касперович. Проте до цього моменту не було проаналізовано переваги використання дистанційної зайнятості для роботодавців в Україні в умовах епідемії, не було визначено макроекономічні ефекти від поширення дистанційної зайнятості.

Постановка завдання. Метою дослідження є: а) проаналізувати переваги використання дистанційної зайнятості для роботодавців в Україні в умовах епідемії; б) визначити макроекономічні ефекти від поширення дистанційної зайнятості.

Стаття містить проміжні результати дослідження, що опубліковано автором в аналітичній записці Національного інституту стратегічних досліджень під назвою «Поширення дистанційної зайнятості як фактор підвищення економічної стійкості» [10], які у даному випадку носять ознайомчий характер для кращого обгрунтування розроблених положень.

Методологія. Для досягнення мети дослідження було використано теоретичні методи, а саме структурно-функціональний, метод порівняння, логічний аналіз, метод узагальнення.

Результати досліджень. Поширення COVID-19 спричинило виникнення низки ризиків для економічної безпеки України, дія яких посилюватиметься в міру продовження карантину. 3 високою ймовірністю загрози для економічної безпеки залишатимуться підвищеними у найближчі 12-18 місяців та обумовлять суттєвий вплив на зниження економічної безпеки громадян (звільнення працівників, зниження доходів домогосподарств), корпоративного сектору та МСП (втрата ринків збуту, погіршення фінансового стану та збільшення числа банкрутств компаній), а також держави в цілому (погіршення стану системи державних фінансів тощо) [8, с.1].

У дослідженні $[8$, с.3] вказано, що карантинні заходи в Україні призведуть до зниження ВВП на рівні 3,5 \% - 7,7 \%. Сукупні втрати Державного та місцевого бюджетів можуть сягнути 150-200 млрд грн. При цьому близько $600-$ 700 тисяч підприємств, малих підприємців та установ сфери освіти, які забезпечують роботою 3,5-4 млн осіб, вже зупинили роботу через карантин. Це близько $1 / 4$ зайнятих в економіці України $[8$, с.3].

Фахівцями НІСД були запропоновані наступні заходи [9] послаблення негативних соціальних наслідків заходів карантину: надати можливість фізичним особам-підприємцям, які вимушено припинили роботу у зв'язку з карантинними 
заходами, тимчасово реєструватися у Державній службі зайнятості як безробітним без закриття ФОП з отриманням допомоги по безробіттю згідно ст. 47 Закону України «Про зайнятість населення»; законодавчо обмежити можливість звільнення працівників на період карантину; забезпечити нормативно-правове врегулювання дистанційного типу зайнятості в Україні, включаючи соціальний захист працівників 3 «віддаленим робочим місцем»; створити спеціальні консультативні пункти у центрах зайнятості в регіонах, в яких відзначено наймасовіше повернення трудових мігрантів, для сприяння їх реінтеграції на національному ринку праці, доступу до підвищення кваліфікації та перекваліфікації, правових та фінансових консультацій щодо започаткування власного бізнесу; активізувати роботу соціальних служб із забезпечення доступу мігрантів та членів їхніх родин до соціальної допомоги, на яку вони мають право відповідно до законодавства [9, с. 5].

У багатьох українських компаніях, установах і організаціях, які керуються сучасними управлінськими підходами в роботі, дистанційна зайнятість як форма організації праці тією чи іншою мірою вже була випробувана на практиці, оскільки має низку переваг у порівнянні з традиційною роботою. До головних 3 них належать [10]: розширення географії залучення робочої сили, що дозволяє роботодавцю винаймати працівників з унікальними компетенціями в будь-якому регіоні країни та поза їі межами; збереження трудових відносин з працівниками, які тимчасово $\epsilon$ активно залученими до виконання батьківських або інших сімейних обов'язків; можливість здійснювати ефективну координацію роботи підлеглих керівниками, робота яких потребує частих (тривалих) відряджень або передбачає робочі зустрічі поза основним робочим місцем; можливість реалізації проектного підходу до найму робочої сили, відповідно до якого спеціалісти винаймаються не на постійній основі, а під виконання роботи в межах реалізації конкретних проектів; роботодавцям такий підхід дозволяє регулювати ступінь зайнятості кожного з працівників в межах виробничої необхідності, працівники, у свою чергу, можуть самостійно регулювати своє робоче навантаження, підключаючись, за наявності бажання, до кількох проектів різних роботодавців; економія роботодавця на видатках на фізичне утримання робочих місць; уникнення простою у роботі, зумовленого неможливістю для працівника бути фізично присутнім на робочому місці.

Запровадження загальнонаціональних карантинів через пандемію COVID19 в більшості розвинених країн показало, що остання перевага дистанційної зайнятості має вирішальне значення для збереження нормальної виробничої діяльності компаній і організацій в умовах вимушених суворих обмежень на пересування громадян, що накладаються державою. Незважаючи на те, що 
окремі види діяльності (як товарне виробництво, сфера послуг, розваг, доставка товарів) не можуть виконуватися без фізичної присутності працівників навіть в умовах (часткового) переходу підприємств у сектор е-commerce, загальне керівництво і робота допоміжних підрозділів в більшості випадків може здійснюватися дистанційно. Оскільки в найближчій, a, можливо, i середньостроковій перспективі усі види економічної діяльності доведеться здійснювати в умовах різного ступеня суворості карантинних обмежень, спроможність підприємства, установи чи організації перейти на дистанційний режим роботи стане однією з його головних ринкових переваг. Водночас, частка таких гнучких в організаційному плані підприємств, організацій і установ визначатиме ступінь загальної стійкості національної економіки до епідемічних загроз.

Відтак, поширення дистанційної зайнятості має низку переваг на макроекономічному рівні $[10$, с.4]:

1. Загальне підвищення технологічності економіки. Що більш технологічною є компанія, то легше перевести іiі роботу у режим дистанційної зайнятості. Таким чином, орієнтація бізнесу на дистанційну роботу та (частковий) перехід у e-commerce підвищить його ефективність через використання сучасних технологій. Повсюдне запровадження сучасних технологій (або підвищення їх значення в організації роботи) в тих галузях, де це можливо - освіта, наукова діяльність, консалтинг і аудит, бухгалтерія і фінансова звітність, рекрутинг і робота 3 персоналом, збір і обробка даних, інші види аналітичної діяльності тощо сприятиме загальному підвищенню технологічності економіки.

2. Підвищення соціального захисту працівників. Спроможність компанії або організації переводити свою діяльність у дистанційний режим визначатиме рівень стабільності зайнятості її працівників, адже економічні суб'єкти з низьким рівнем адаптивності вдаються до скорочення персоналу або зменшення оплати праці в умовах вимушеного простою. Для стимулювання бізнесу до переходу до сучасних форм організації праці держава може використовувати економічно обгрунтовані інструменти фіскальної політики. Зокрема, наявність у компанії плану щодо збереження робочих місць у випадку непередбачуваної ситуації може бути підставою для зниження відрахувань на соціальне страхування. У разі, коли трудова угода працівника містить пункти щодо можливості здійснювати роботу дистанційно, збереження робочого місця під час оголошення карантину, зобов'язань роботодавця розділити з працівником непередбачувані видатки, пов'язані з організацією роботи на дому або доїздом до робочого місця у випадку накладання обмежень на роботу громадського транспорту тощо, він 3 
меншою ймовірністю стане безробітним, i, відповідно, вартість його страхування на випадок безробіття може бути зменшена.

3. Підвищення конкурентоспроможності робочої сили. Технічний супровід дистанційної зайнятості передбачає отримання працівниками додаткових компетенцій для роботи з сучасним програмним забезпеченням. Крім того, виконання надомної роботи передбачає активний розвиток низки індивідуальних здібностей, так званих «soft skills», значення яких для побудови кар'єри постійно зростає - самодисципліни, самостійності у плануванні і контролі, самомотивації, здатності до самостійного навчання. Поштовх до набуття сучасних компетенцій отримають традиційно вразливі категорії на ринку праці - представники старших когорт працівників, працівники 3 низьким рівнем освіти. Поширення дистанційної зайнятості сприятиме підвищенню якості та конкурентоспроможності робочої сили в національному масштабі, збільшить іiі внутрішню та зовнішню трудову мобільність.

4. Пом'якшення впливу сезонного підвищення захворюваності на гострі респіраторні інфекції на ринок праці. Запровадження часткового переходу на дистанційний режим роботи (як в масовому, так і в індивідуальному порядку) під час традиційного підвищення захворюваності на гострі респіраторні інфекції в осінньо-зимові періоди дозволить компаніям, установам і організаціям знизити рівень захворюваності серед своїх працівників, що не тільки позитивно позначиться на епідеміологічній ситуації в країни і збереже ресурси системи охорони здоров'я, але й знизить суми державних та приватних видатків на обслуговування непрацездатності.

5. Модернізація бюджетного сектору зайнятості, сфери державного управління. До державного сектору належать традиційно найбільш консервативні сфери зайнятості - освіта, охорона здоров'я, державне управління. Утім, тривалість карантинних заходів і залежність широкого кола осіб від безперервного надання послуг у цих сферах змусили шукати варіанти дистанційної роботи й закладів і установ державного сектору. Зокрема, найбільшого поширення набули програми дистанційного навчання, телеуроки та використання педагогічними працівниками новітніх телекомунікаційних технологій для проведення он-лайн уроків. Міністерством охорони здоров'я України було випробувано використання мобільних месенджерів та інформаційних ресурсів для проведення роз'яснювальної роботи серед населення, яка показує високу ефективність [2]; мобільного додатку, призначеного для контролю за особами, зобов'язаними дотримуватися режиму самоізоляції [3]. Під час карантину місцевими органам влади було визначено перелік послуг, які надаються ЦНАПами та комунальними підприємствами в 
телефонному режимі, або засобами Інтернет-зв'язку, так само на дистанційний режим роботи перейшла більшість працівників секретаріату Кабміну [4]. Незважаючи на те, що використання новітніх технологій в державному секторі зайнятості в нинішньому вигляді розглядається лише як альтернативна традиційним методам роботи на час карантину, напрацювання в організації дистанційної роботи не тільки можуть бути використаними під час виникнення непередбачуваної ситуації в майбутньому, але й здатні розширити функціональність зазначених галузей, надати додаткові можливості у реалізації виробничих завдань.

На ринку праці, так само як і в інших сферах життя, пандемія COVID-19 закріпила більшість тенденцій, що вже мали об'єктивні підстави і передумови для існування, оскільки їх підвалини були попередньо закладені глобальними історичними процесами. Спроможність швидко переорієнтувати бізнес на роботу в нестандартних умовах вже давно $є$ важливим економічним активом [10, c.5].

Введення загальнонаціонального карантину (різного ступеню суворості) 3 метою стримування епідемічної загрози на сьогодні вже $\epsilon$ випробовуваним державним інструментом захисту громадського здоров'я, який, за необхідності, може використовуватися і надалі, змінюючи умови формування конкурентного середовища. Це означає, що економічну кризу успішно подолають ті компанії, установи та організації, які виявлять гнучкість в організації роботи і зможуть забезпечити безперервність свої діяльності за допомогою дистанційної зайнятості. При цьому головними завданнями держави $\epsilon$ : удосконалення нормативно-правого поля відповідно до потреб трудових відносин нової якості, впровадження найкращих практик використання нестандартних форм зайнятості i прогресивних форм організації праці у державному секторі, формування здорового конкурентного середовища через встановлення рекомендованих регламентів переходу підприємств і організацій на дистанційний режим роботи у випадку непередбачуваної ситуації.

Висновки. Останні законодавчі зміни щодо унормування дистанційної зайнятості можна охарактеризувати як такі, що закріпили ситуацію 3 дистанційною роботою, що вже фактично склалася на багатьох вітчизняних підприємствах і в організаціях після оголошення у березні 2020 p. загальнонаціонального карантину у зв'язку з поширенням COVID-19. Водночас проактивна політика держави щодо поширення дистанційної зайнятості може виступити важливою передумовою для підвищення загальної економічної стійкості держави в умовах перманентних епідемічних загроз. Реалізація такої політики передбачає формування нормативно-правових засад розвитку нестандартних форм зайнятості, використання прогресивних форм організації 
праці у державному секторі, стимулювання поширення дистанційної зайнятості на підприємствах та в організаціях усіх форм власності.

\section{Література:}

1. Закон України «Про внесення змін до деяких законодавчих актів України, спрямованих на забезпечення додаткових соціальних та економічних гарантій у зв'язку з поширенням коронавірусної хвороби (COVID-19)» № 540-IX від 30 березня 2020 p. [Електронний pecypc]. URL: https://zakon.rada.gov.ua/laws/show/540-20 (дата доступу 14.04.2020).

2. Индекс соблюдения самоизоляции. [Електронний pecypc]. URL: https://kyivstar.ua/ru/covid2019-stat (дата доступу 14.04.2020).

3. «Дій вдома». [Електронний ресурс]. URL: https://www.kmu.gov.ua/news/projdi-observaciyuvdoma

4. Слово і діло. Переважна більшість Кабміну перейшла на дистанційний режим роботи [Електронний ресурc]. URL: https://www.slovoidilo.ua/2020/04/10/novyna/polityka/perevazhnachastyna-kabminu-perejshladystanczijnyj-rezhym-roboty (дата доступу 14.04.2020).

5. Паламарчук М. Новий світовий порядок: тепер кожен сам за себе. Виживання України залежить лише від нашої ефективності. [Електронний ресурс]. URL: https://texty.org.ua/articles/100866/novyj-svitovyj-poryadok-teper-kozhen-sam-za-sebevyzhyvannya-ukrayiny-zalezhyt-lyshe-vid-nashoyiefektyvnosti/?fbclid=IwAR1JNtzRIznaUHXvQL4e_KfgINzaPLN8z6MQ8yNrX6j7XOctcqvUNh qBdMk (дата доступу 14.04.2020).

6. Веселовський А. I., Александров О. С., Орлик В. В. Вплив пандемії COVID-19 на розвиток глобальних процесів розвитку системи міжнародних відносин [Електронний ресурс]. URL: https://niss.gov.ua/sites/default/files/2020-05/covid-i-globalni-procesy-1.pdf (дата доступу 14.04.2020).

7. Малиновська О. А. Вплив пандемії covid-19 на трудову міграцію громадян України та можливі напрями державного реагування. [Електронний ресурс]. URL: https://niss.gov.ua/sites/default/files/2020-05/trudova-migratsiya.pdf (дата доступу 14.04.2020).

8. Базилюк Я. Б.,. Гейко Т. Ю. Організаційні механізми зниження загроз економічній безпеці у зв'язку із запровадженням заходів щодо запобігання поширенню на території України захворювань на COVID-19. [Електронний pecypc]. URL: https://niss.gov.ua/sites/default/files/2020-04/ekonom-bezpeka-covid.pdf (дата доступу 14.04.2020).

9. Щодо подолання негативних соціально-економічних наслідків заходів, спрямованих на обмеження поширення Covid-19 В Україні [Електронний pecypc]. URL: https://niss.gov.ua/sites/default/files/2020-03/tezy-covid19.pdf (дата доступу 14.04.2020).

10. Коломієць О.О. Поширення дистанційної зайнятості як фактор підвищення економічної стійкості. [Електронний pecypc]. URL: https://niss.gov.ua/sites/default/files/202004/dystantsiyna-zaynyatist_0.pdf (дата доступу 14.04.2020). 


\section{References:}

1. The Verkhovna Rada of Ukraine (2020), On Amendments to Certain Legislative Acts of Ukraine Aimed at Providing Additional Social and Economic Guarantees in Connection with the Spread of Coronavirus (COVID-19), Available at: https://zakon.rada.gov.ua/laws/show/540-20 (Accessed 14 Apr 2020).

2. Indeks sobljudenija samoizoljacii (2020), Available at: https://kyivstar.ua/ru/covid2019-stat (Accessed 14.04.2020).

3. "Dij vdoma" (2020), Available at: https://www.kmu.gov.ua/news/projdi-observaciyu-vdoma (Accessed 14 Apr 2020).

4. Slovo i dilo (2020), The vast majority of the Cabinet of Ministers switched to remote operation, Available at: https://www.slovoidilo.ua/2020/04/10/novyna/polityka/perevazhna-chastynakabminu-perejshladystanczijnyj-rezhym-roboty (Accessed 14 Apr 2020).

5. Palamarchuk, M. (2020), A new world order: now everyone is on his own. Ukraine's survival depends only on our efficiency, Available at: https://texty.org.ua/articles/100866/novyj-svitovyjporyadok-teper-kozhen-sam-za-sebe- vyzhyvannya- ukrayiny- zalezhyt- lyshe- vid- nashoyiefektyvnosti/?fbclid=IwAR1JNtzRIznaUHXvQL4e_KfgINzaPLN8z6MQ8yNrX6j7XOctcqvUNh qBdMk (Accessed 14 Apr 2020).

6. Veselovs'kyj, A. I., Aleksandrov, O. S. and Orlyk, V. V. (2020), The impact of the COVID-19 pandemic on the development of global processes in the development of the system of international relations, Available at: https://niss.gov.ua/sites/default/files/2020-05/covid-i-globalni-procesy1.pdf (Accessed 14 Apr 2020).

7. Malynovs'ka, O. A. (2020), The impact of the covid-19 pandemic on labor migration of Ukrainian citizens and possible directions of state response, Available at: https://niss.gov.ua/sites/default/files/2020-05/trudova-migratsiya.pdf (Accessed 14 Apr 2020).

8. Bazyliuk, Ya. B. and Hejko, T. Yu (2020), Organizational mechanisms to reduce threats to economic security in connection with the introduction of measures to prevent the spread of COVID-19 in Ukraine, Available at: https://niss.gov.ua/sites/default/files/2020-04/ekonombezpeka-covid.pdf (Accessed 14 Apr 2020).

9. "Schodo podolannia nehatyvnykh sotsial'no-ekonomichnykh naslidkiv zakhodiv, spriamovanykh na obmezhennia poshyrennia Covid-19 V Ukraini” (2020), Available at: https://niss.gov.ua/sites/default/files/2020-03/tezy-covid19.pdf (Accessed 14 Apr 2020).

10. Kolomiiets', O.O. (2020), "The spread of remote employment as a factor in increasing economic stability", Available at: https://niss.gov.ua/sites/default/files/2020-04/dystantsiynazaynyatist_0.pdf (Accessed 14 Apr 2020). 